\title{
PERAMALAN BEBAN LISTRIK DAERAH ISTIMEWA YOGYAKARTA DENGAN METODE SINGULAR SPECTRUM ANALYSIS (SSA)
}

\author{
Herni Utami ${ }^{1}$, Yunita Wulan Sari $^{2}$, Subanar $^{3}$, Abdurakhman $^{4}$, Gunardi $^{5}$ \\ 1,2,3,4,5 Departemen Matematika, FMIPA Universitas Gadjah Mada \\ e-mail: herni_utami@ugm.ac.id
}

DOI: 10.14710/medstat.12.2.214-225

\section{Article Info: \\ Received: 24 November 2018 \\ Accepted: 21 December 2019 \\ Available Online: 30 December 2019}

Keywords:

Forecasting model, Singular Spectral Analysis, Linear

Recurrent Formula,

Electricity demand

\begin{abstract}
This paper will study forecasting model for electricity demand in Yogyakarta and forecast it for 2019 until 2024. Usually, electricity demand data contain seasonal. We propose Singular Spectral Analysis-Linear Recurrent Formula (SSA-LRF) method. The SSA process consists of decomposing a time series for signal extraction and then reconstructing a less noisy series which is used for forecasting. The SSA-LRF method will be used to forecast h-step ahead. In this study, we use monthly electricity demand in Yogyakarta for 11 year (2008 to 2018). The forecasting results indicates that the forecast using window length of $\mathrm{L}=26$ have good performance with MAPE of $1.9 \%$.
\end{abstract}

\section{PENDAHULUAN}

Listrik merupakan salah satu sumber energi yang sangat dibutuhkan oleh manusia, baik untuk memenuhi kebutuhan rumah tangga dan industri maupun untuk memenuhi kebutuhan umum seperti penerangan di jalan-jalan. Saat ini, kebutuhan listrik terutama di Daerah Istimewa Yogayakarta (DIY) sangat besar. Di sisi lain, listrik adalah salah satu sumber energi yang tidak bisa diperbaharui (Setiawan, 2014). Pemerintah sudah berupaya menambah pembangkit listrik, namun usaha ini membutuhkan proses yang lama dan biaya yang besar. Oleh karena itu, perlu dilakukan langkah-langkah perencanaan dan strategi untuk mengatur penyediaan dan penggunaan listrik di DIY agar kebutuhan listrik masyarakat bisa terpenuhi dalam jangka waktu panjang. Untuk membuat perencanaan dan strategi yang baik perlu dilakukan studi untuk melihat besarnya kebutuhan listrik di waktuwaktu mendatang. Salah satu langkah penting adalah dengan melakukan peramalan kebutuhan listrik.

Banyak model dan metode untuk meramalkan suatu data runtun waktu, akan tetapi tidak semuanya cocok jika diterapkan untuk kasus kebutuhan listrik di DIY. Model dan metode peramalan yang baik harus sesuai dengan karakteristik data yang akan diramalkan. Karakteristik data listrik biasanya mengandung trend dan musiman dengan jenis musiman bisa lebih dari satu.

Beberapa peneliti sudah melakukan studi untuk menentukan model ramalan listrik, diantaranya Ringwood dan Bofelli (2001), Weron dan Misiorek (2008), serta Afsar dan 
Bigdeli (2011). Sedangkan beberapa penelitian tentang ramalan listrik di Indonesia terutama di Yogyakarta diantaranya dilakukan oleh Dafroni, dkk (2015) yang meramalkan kebutuhan listrik di DIY dengan menggunakan metode ekonometri, Harmawan (2013) yang meramalkan beban listrik harian Jawa Tengah dan Yogyakarta menggunakan metode SARIMA. Peneliti lain seperti Pratama dan Anifah (2016), Nugraheni (2017), dan Pamungkas, (2013) meramalkan beban listrik di DIY menggunakan berbagai metode yaitu Neural Network Backpropagation, Fuzzy Radial Basis Neural Network, dan double seasonal eksponential smoothing. SSA (singular spectrum analysis) merupakan suatu metode yang dapat digunakan untuk mendekomposisikan runtun waktu berpola musiman kompleks menjadi beberapa komponen yang lebih sederhana dan mudah diinterpretasikan. SSA merupakan teknik dengan model bebas dikarenakan SSA tidak seperti model parametrik, yang mengasumsikan normalitas dari runtun waktu. Data listrik diduga mengandung musiman lebih dari satu, dan cenderung mengandung tren. Oleh karena itu, dalam paper ini, akan dilakukan peramalan kebutuhan listrik di Yogyakarta dengan menggunakan Singular Spectral Analysis-Linear Recurrent Formula (SSA-LRF).

\section{TINJAUAN PUSTAKA}

SSA adalah suatu teknik untuk mendekomposisikan runtun waktu menjadi beberapa komponen pola sehingga lebih mudah diinterprestasikan, misalnya komponen trend, musiman dan iregular. Metode SSA tidak memerlukan asumsi khusus, sehingga memperluas area penggunaannya (Golyandina dan Korobeynikov, 2014). Metode ini banyak digunakan pada analisis iklim, meteorologi dan geofisika (Vautard and Ghil, 1989; Ghil dan Vautard, 1991).

Dalam perkembangannya, SSA juga digunakan dalam peramalan data ekonometri (Hassani, 2009) serta Indeks Harga Konsumen (Lubis, 2017). Metode SSA terdiri dari 4 tahap (Elsner and Tsonis, 1996; Golyandina, dkk, 2001; Hassani, 2007; Golyandina and Zhigljavsky, 2013), yaitu

a. Tahap embedding (penentuan matriks trajektori, $\mathbf{X}$ )

b. Tahap dekomposisi nilai singular (singular value decomposition atau SVD)

c. Tahap pengelompokan eigentriple

d. Tahap rekonstruksi runtun waktu berdimensi satu melalui metode rata-rata Diagonal

\subsection{Tahap Embedding}

Pada tahap ini diperlukan penentuan parameter window length (L) dengan ketentuan $2 \leq L \leq n, n$ merupakan banyaknya observasi. Embedding dapat dipandang sebagai pemetaan sebuah runtun waktu berdimensi satu $\mathbf{f}=\left\{f_{0}, f_{1}, \ldots, f_{n-1}\right\}$ menjadi deret multidimensional $\mathbf{X}_{1}, \ldots, \mathbf{X}_{k} \quad$ dengan vektor $\quad \mathbf{X}_{i}=\left(f_{i-1} f_{i} \ldots f_{i+L-2}\right)^{T} \in \square^{L} \quad$ dengan $k=n-L+1$. Embedding dapat juga didefinisikan sebagai transformasi $\mathbf{f}$ ke matriks trajektori , dengan baris-baris dan kolom-kolomnya berupa sub-sub runtun waktu dari f . Matriks trajektori ini dapat dinyatakan sebagai: 


$$
\mathbf{X}=\left[\begin{array}{ccccccc}
f_{0} & f_{1} & f_{2} & \cdots & f_{k-3} & f_{k-2} & f_{k-1} \\
f_{1} & f_{2} & f_{3} & \cdots & f_{k-2} & f_{k-1} & f_{k} \\
f_{2} & f_{3} & f_{4} & \cdots & f_{k-1} & f_{k} & f_{k+1} \\
\vdots & \vdots & \vdots & \ddots & \vdots & \vdots & \vdots \\
f_{L-3} & f_{L-2} & f_{L-1} & \cdots & f_{n-5} & f_{n-4} & f_{n-3} \\
f_{L-2} & f_{L-1} & f_{L} & \cdots & f_{n-4} & f_{n-3} & f_{n-2} \\
f_{L-1} & f_{L} & f_{L+1} & \cdots & f_{n-3} & f_{n-2} & f_{n-1}
\end{array}\right]
$$

\subsection{Tahap Singular Value Decomposition (SVD)}

Tahap kedua dari dekomposisi adalah pembentukan SVD dari matriks lintasan $\mathbf{X}$. SVD merupakan suatu teknik untuk mendekomposisikan matriks untuk mempermudah pengolahan data. SVD dari matriks $\boldsymbol{X}$ adalah faktorisasi dalam bentuk

$$
X=U \Sigma_{r} V^{T}
$$

dengan $\boldsymbol{U}$ adalah matriks orthogonal berukuran $L \times L, \boldsymbol{\Sigma}_{r}$ adalah matriks diagonal rektangular berukuran $L \times k$ dengan elemen-elemen pada diagonal adalah riil non-negatif, dan $\boldsymbol{V}$ adalah matriks orthogonal berukuran $k \times k$. Kolom-kolom dari matriks $\boldsymbol{U}$ dan kolom-kolom dari matriks $\boldsymbol{V}$ secara berturut-turut disebut dengan vektor singular kiri dan vektor singular kanan dari matriks $\boldsymbol{X}$.

Vektor singular kiri dari matriks $\boldsymbol{X}$ adalah himpunan vektor-vektor eigen ortonormal dari matriks $\boldsymbol{X} \boldsymbol{X}^{\boldsymbol{T}}$ dan vektor singular kanan dari matriks $\boldsymbol{X}$ adalah himpunan vektor-vektor eigen ortonormal dari $\boldsymbol{X}^{\boldsymbol{T}} \boldsymbol{X}$. Matriks $\boldsymbol{X} \boldsymbol{X}^{\boldsymbol{T}}$ dan matriks $\boldsymbol{X}^{\boldsymbol{T}} \boldsymbol{X}$ adalah matriksmatriks simetriks, yaitu

$$
\begin{aligned}
\boldsymbol{X} \boldsymbol{X}^{\boldsymbol{T}} & =\boldsymbol{U} \boldsymbol{\Sigma}_{r} \boldsymbol{V}^{T}\left(\boldsymbol{U} \Sigma_{r} \boldsymbol{V}^{T}\right)^{T} \\
& =\boldsymbol{U} \Sigma_{r} \boldsymbol{V}^{T} \boldsymbol{V} \Sigma_{r}{ }^{T} \boldsymbol{U}^{T} \\
& =\boldsymbol{U} \Sigma_{r} I \Sigma_{r}{ }^{T} \boldsymbol{U}^{T} \\
& =\boldsymbol{U} \Sigma_{r} \Sigma_{r}{ }^{T} \boldsymbol{U}^{T}
\end{aligned}
$$

dan

$$
\begin{aligned}
\boldsymbol{X}^{\boldsymbol{T}} \boldsymbol{X} & =\left(\boldsymbol{U} \boldsymbol{\Sigma}_{r} \boldsymbol{V}^{\boldsymbol{T}}\right)^{\boldsymbol{T}} \boldsymbol{U} \boldsymbol{\Sigma}_{r} \boldsymbol{V}^{\boldsymbol{T}} \\
& =\boldsymbol{V} \boldsymbol{\Sigma}_{r}^{\boldsymbol{T}} \boldsymbol{U}^{\boldsymbol{T}} \boldsymbol{U} \boldsymbol{\Sigma}_{r} \boldsymbol{V}^{\boldsymbol{T}} \\
& =\boldsymbol{V} \boldsymbol{\Sigma}_{r}^{T} \boldsymbol{I} \boldsymbol{\Sigma}_{r} \boldsymbol{V}^{\boldsymbol{T}} \\
& =\boldsymbol{V} \boldsymbol{\Sigma}_{r}^{T} \boldsymbol{\Sigma}_{r} \boldsymbol{V}^{\boldsymbol{T}}
\end{aligned}
$$

Di sisi lain, $\boldsymbol{S}=\boldsymbol{X} \boldsymbol{X}^{\boldsymbol{T}}$ adalah matriks simetris berukuran $L \times L$ sehingga dapat dinyatakan sebagai

$$
S=X X^{T}=U \Lambda U^{T}
$$

dengan $\boldsymbol{U}$ adalah matriks orthogonal yang kolom-kolomnya adalah vektor-vektor eigen (orthonormal) dari $\boldsymbol{S}$ dan $\boldsymbol{\Lambda}$ adalah matriks diagonal dengan elemen-elemen diagonal merupakan nilai-nilai eigen dari $\boldsymbol{S}$. Dengan demikian, dari Persamaan (3), (4) dan (5) diperoleh 


$$
\boldsymbol{U} \boldsymbol{\Sigma}_{r} \boldsymbol{\Sigma}_{r}^{T} \boldsymbol{U}^{T}=\boldsymbol{\Lambda}
$$

Nilai-nilai singular yang tidak nol dari $\boldsymbol{X}$ adalah elemen-elemen diagonal $\boldsymbol{\Sigma}_{r}$ yang merupakan akar dari nilai-nilai eigen $\boldsymbol{X} \boldsymbol{X}^{\boldsymbol{T}}$ dan $\boldsymbol{X}^{\boldsymbol{T}} \boldsymbol{X}$.

Pada tahap SVD, matriks trajektori $\boldsymbol{X}$ didekomposisikan menjadi

$$
\boldsymbol{X}=\left(\begin{array}{ccc}
U_{11} & \cdots & U_{1 L} \\
\vdots & \ddots & \vdots \\
U_{L 1} & \cdots & U_{L L}
\end{array}\right)\left(\begin{array}{ccccc}
\sqrt{\lambda_{1}} & \cdots & 0_{L} & \cdots & 0_{k} \\
\vdots & \ddots & \vdots & \ddots & \vdots \\
0_{L} & \cdots & \sqrt{\lambda_{L}} & \cdots & 0_{k}
\end{array}\right)\left(\begin{array}{ccc}
V_{11} & \cdots & V_{1 k} \\
\vdots & \ddots & \vdots \\
V_{K 1} & \cdots & V_{k k}
\end{array}\right)
$$

Diasumsikan $L<k$, sehingga rank maksimal dari matriks $\boldsymbol{\Sigma}_{r}$ adalah $L$. Nilai-nilai singular $\sqrt{\lambda_{i}}(i=1,2, \ldots, L)$ disusun secara berurutan dari yang paling besar hingga ke nilai yang paling kecil. Jika $d=\operatorname{rank}(\boldsymbol{X})=\max \left\{i \mid \sqrt{\lambda_{\boldsymbol{i}}}>0\right\}$ maka persamaan (6) dapat dinyatakan sebagai

$$
\boldsymbol{X}=\sum_{i=1}^{d} \sqrt{\lambda_{i}} \boldsymbol{U}_{i} \boldsymbol{V}_{\boldsymbol{i}}^{T}
$$

Himpunan $\left\{\boldsymbol{U}_{1}, \ldots, \boldsymbol{U}_{d}\right\}$ beranggotakan vektor-vektor eigen (ortonormal) dari matriks $\boldsymbol{X X}^{\boldsymbol{T}}$ dan $\boldsymbol{V}_{i}(i=1, \ldots, d)$ yang ditentukan menggunakan persamaan (2). Misal matriks trajektori pada Persamaan (1) dinyatakan sebagai $\boldsymbol{X}=\left(\boldsymbol{X}_{1} \ldots \boldsymbol{X}_{k}\right)$ dengan $\mathbf{X}_{j}=\left(f_{j-1} f_{j} \ldots f_{j+L-2}\right)^{T}$ untuk setiap $j=1, \ldots, k$. Vektor $\mathbf{0}_{r}=\left(\begin{array}{lll}0 & 0 \ldots\end{array}\right)$ adalah vektor kolom berukuran $r<d$ dan $\mathbf{0}_{r_{1} \times r_{2}}$ adalah matriks null berukuran $r_{1} \times r_{2}$. Selanjutnya matriks $\boldsymbol{U}$ dinyatakan sebagai

$$
\boldsymbol{U}=\left\{\begin{array}{lll}
\boldsymbol{U}_{1} & \ldots & \boldsymbol{U}_{L}
\end{array}\right\}
$$

dengan $\boldsymbol{U}_{i}=\left(U_{1 l} \ldots U_{L l}\right)^{T}$ untuk setiap $i=1, \ldots, L$ dan matriks $\boldsymbol{V}$ dinyatakan sebagai

$$
\boldsymbol{V}=\left\{\begin{array}{lll}
\boldsymbol{V}_{1} & \ldots & \boldsymbol{V}_{k}
\end{array}\right\}
$$

dengan $\boldsymbol{V}_{j}=\left(V_{1 j} \ldots V_{k j}\right)^{T}$ untuk setiap $j=1, \ldots, k$. Berdasarkan sifat orthogonal matriks $\boldsymbol{U}$ dan Persamaan (2) diperoleh

$$
\mathbf{V} \boldsymbol{\Sigma}_{r}^{T}=\boldsymbol{X}^{T} \boldsymbol{U}
$$

Sehingga

$$
\left(\begin{array}{lllll}
\boldsymbol{V}_{1} \sqrt{\lambda_{1}} & \ldots & \boldsymbol{V}_{d} \sqrt{\lambda_{d}} & \mathbf{0}_{(k-d) \times(L-d)}
\end{array}\right)=\left(\begin{array}{lll}
X^{T} U_{1} & \ldots & X^{T} U_{L}
\end{array}\right)
$$

Dengan kata lain $\boldsymbol{V}_{i} \sqrt{\lambda_{\boldsymbol{i}}}=\boldsymbol{X}^{\boldsymbol{T}} \boldsymbol{U}_{i}$ atau $\boldsymbol{V}_{i}=\boldsymbol{X}^{\boldsymbol{T}} \boldsymbol{U}_{i} / \sqrt{\lambda_{\boldsymbol{i}}}$ untuk $i=1, \ldots, d$. SVD matriks trajektori $\boldsymbol{X}$ pada Persamaan (7) dapat dituliskan sebagai

$$
\boldsymbol{X}=\boldsymbol{X}^{(\mathbf{1})}+\cdots+\boldsymbol{X}^{(\boldsymbol{d})}
$$

dengan $\boldsymbol{X}^{(i)}=\sqrt{\lambda_{\boldsymbol{i}}} \boldsymbol{U}_{i} \boldsymbol{V}_{i}{ }^{T}$ dan $\left(\sqrt{\lambda_{\boldsymbol{i}}}, \boldsymbol{U}_{i}, \boldsymbol{V}_{i}\right)$ disebut eigentriple ke-i dari SVD matriks (8).

\subsection{Tahap Pengelompokan Eigentriple}

Pengelompokan eigentriple adalah suatu prosedur untuk mempartisi himpunan indeks $\{1, \ldots, d\}$ menjadi sejumlah $m$ grup himpunan yang saling asing $I_{1}, \ldots, I_{m}$. Misalkan $I=\left\{i_{1}, i_{2}, \ldots, i_{p}\right\}$ merupakan himpunan indeks $i_{1}, i_{2}, \ldots, i_{p}$. Maka matriks $\mathbf{X}_{I}$ yang sesuai dengan himpunan $I$ didefinisikan dengan $\mathbf{X}_{I}=\mathbf{X}_{i_{1}}+\ldots+\mathbf{X}_{i_{p}}$. Sehingga, Persamaan (8) menjadi

$$
\mathbf{X}=\mathbf{X}^{\left(I_{1}\right)}+\ldots+\mathbf{X}^{\left(I_{m}\right)}
$$


Cara untuk memilih himpunan $I_{1}, \ldots, I_{m}$ disebut eigentriple grouping.

Menurut Rosmalawati, dkk (2014), pada langkah ini matriks trajektori diuraikan manjadi beberapa sub-himpunan, yaitu pola tren, musiman, periodik, dan noise. Pada tahap grouping, matriks $\mathbf{X}^{(i)}$ pada Persamaan (8) dibagi menjadi beberapa kelompok dan menjumlahkan matriks dalam masing-masing kelompok. Tujuan dari tahap grouping ini adalah pemecahan (separation) komponen tambahan dari runtun waktu (Golyandina, dkk, 2001).

\subsection{Tahap rekonstruksi}

Pada tahap ini, akan dilakukan transformasi dari hasil pengelompokan matriks pada Persamaan (9) menjadi sebuah runtun waktu baru dengan panjang $n$. Langkah dasar untuk melakukan tahap ini adalah dengan mengubah bentuk dari matriks $\mathbf{X}^{\left(I_{i}\right)}$ dari tahap rekonstruksi menjadi matrik Hankel. Cara optimal untuk melakukannya adalah dengan mencari rata-rata semua elemen pada beberapa antidiagonal dengan persamaan berikut

$$
\tilde{f}_{j}^{\left(I_{i}\right)}=\left\{\begin{array}{c}
\frac{1}{j} \sum_{t=1}^{j} f_{t, j-t+1}^{\left(I_{i}\right)} \quad \text { jika } 1 \leq j<l^{*}, \\
\frac{1}{l^{*}} \sum_{t=1}^{l^{*}} f_{t, j-t+1}^{\left(I_{i}\right)} \quad \text { jika } l^{*} \leq j \leq k^{*}, \\
\frac{1}{n-j+1} \sum_{t=j-k^{*}+1}^{n-k^{*}+1} f_{t, j-t+1}^{\left(I_{i}\right)} \quad j i k a k^{*}<j \leq n .
\end{array}\right.
$$

dengan $l^{*}=\min (L, k)$ dan $k^{*}=\max (L, k)$. Persamaan (10) tersebut kemudian diaplikasikan ke dalam matriks pada Persamaan (9), $\mathbf{X}^{\left(I_{i}\right)}$ akan membentuk series $\tilde{\mathbf{f}}^{\left(I_{i}\right)}=\left(\tilde{f}_{1}^{\left(I_{i}\right)}, \ldots, \tilde{f}_{n}^{\left(I_{i}\right)}\right)$. Sehingga series awal $\mathbf{f}=\left(f_{1}, f_{2}, \ldots, f_{n}\right)$ akan didekomposisi menjadi jumlahan dari $m$ series $f_{j}=\sum_{i=1}^{m} \tilde{f}_{j}^{\left(I_{i}\right)}$ untuk $\mathrm{j}=1,2, . ., \mathrm{n}$.

\subsection{SSA Forecasting}

Menurut Hassani (2009), sebuah runtun waktu f memenuhi Linear Recurrent Formula (LRF) jika terdapat $a_{1}, a_{2}, \ldots, a_{l-1}$ sehingga

$$
f_{n-i}=\sum_{k=1}^{l-1} a_{k} f_{n-i-k} \quad \text { untuk } 0 \leq i \leq n-l
$$

Untuk memperoleh koefisien LRF, digunakan vektor eigen yang diperoleh dari langkah SVD. Misalkan $\mathbf{U}=\left(u_{1}, u_{2}, \ldots, u_{l-1}, u_{l}\right)^{T}, \quad \mathbf{U}^{\nabla}=\left(u_{1}, u_{2}, \ldots, u_{l-1}\right)^{T}, \quad$ dan $\pi_{i}$ merupakan komponen terakhir dari vektor eigen $\mathbf{U}$, atau dapat dituliskan dengan $\pi_{i}=\mathbf{U}_{L}$. Koefisien LRF dapat dihitung dengan persamaan

$$
\mathbf{A}=\left(a_{1}, a_{2}, \ldots, a_{l-1}\right)^{T}=\frac{1}{1-v^{2}} \sum_{i=1}^{r} \pi_{i} \mathbf{U}_{i}^{\nabla}
$$

dengan $v^{2}=\sum_{i=1}^{r} \pi_{i}^{2}$ dan $r$ menunjukkan jumlah eigentriple penting yang membentuk $\mathbf{U}$. 
Deret waktu yang digunakan dalam peramalan SSA adalah deret hasil rekonstruksi yang diperoleh dari tahap diagonal averaging. Misalkan akan diramalkan $p$ data, maka akan terbentuk deret hasil peramalan yaitu $\mathbf{f}_{n+p}=\left(f_{0}, f_{1}, \ldots, f_{n+p-1}\right)$ dengan

$$
f_{i}=\left\{\begin{array}{cl}
\tilde{f}_{i} & \text { untuk } i=0, \ldots, n-1 \\
\sum_{j=1}^{l-1} a_{j} \tilde{f}_{i-j} & \text { untuk } i=n, \ldots, n+p-1
\end{array}\right.
$$

dengan $f_{n}, f_{n+1}, \ldots, f_{n+p}$ merupakan hasil peramalan dengan menggunakan SSA.

\section{METODE PENELITIAN}

Penelitian ini bertujuan untuk meramalkan beban listrik di Propinsi Daerah Istimewa Yogyakarta dengan metode SSA-LRF. Data yang digunakan sebagai studi kasus adalah data bulanan beban listrik dari Januari 2008 sampai dengan Desember 2018. Data sekunder tersebut diperoleh dari BPS Propinsi DIY. Pada analisis dengan SSA-LRF ini, data dibagi menjadi 2 bagian yaitu in-sample dan out-sample. Data beban listrik tahun 2008-2016 yang terdiri dari 108 observasi digunakan sebagai data in-sample, sedangkan data beban listrik tahun 2017-2018 (24 observasi) digunakan sebagai data out-sample. Karena data yang digunakan adalah data bulanan, maka parameter L (window length) ditentukan sebesar 6 dan kelipatannya. Kemudian nilai Mean Absolute Percentage Error (MAPE) untuk masing-masing L dibandingkan untuk mendapatkan model terbaik.

\section{HASIL DAN PEMBAHASAN}

Pemodelan dengan metode SSA-LRF, window length dapat ditentukan menggunakan periode dari pola musiman yang terjadi pada data. Dari plot ACF telah diperoleh periode dari pola musiman dengan panjang musiman 6. Penentuan window length (L) juga dapat dilakukan dengan cara trial and error seperti yang dilakukan oleh Lubis, dkk (2017). Nilai L diambil dari nilai kelipatan 6 dengan memilih nilai RMSE, MAPE, dan MAE terkecil. Banyaknya data adalah 108, sehingga nilai L yang mungkin adalah $L \leq 54$. Hasil dari percobaan yang diperoleh dari cara trial and error disajikan dalam Tabel 1 .

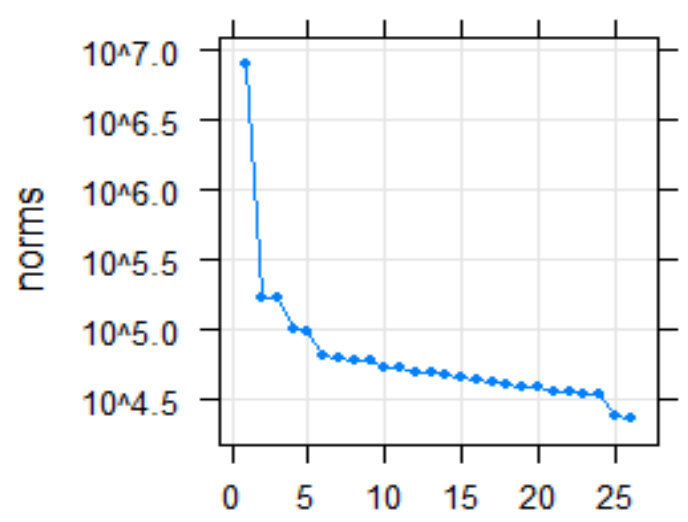

Gambar 1 Plot Nilai Eigen 
Hassani (2009) mengatakan bahwa biasanya setiap komponen harmonik dengan frekuensi yang berbeda memproduksi 2 eigentriple dengan nilai singular yang dekat. Sebuah noise akan menghasilkan barisan nilai singular yang menurun secara perlahan. Pada Gambar 1, terlihat bahwa nilai eigen komponen pertama memiliki nilai yang paling besar dan patahan scree plot berada pada komponen kedua, yang berarti pengaruh komponen pertama sangat besar terhadap pembentukan rekonstruksi sinyal pada data. Terlihat pula bahwa terdapat dua pasang nilai singular yang hampir sama, yaitu pasangan eigentriple 2-3 dan 4-5. Sehingga, kedua pasang eigentriple tersebut dapat dijadikan sebagai calon komponen harmonik dari series kedua dan memiliki periode yang spesifik.

Pada Gambar 2, pasangan eigentriple 2-3 dan 4-5 memiliki periode 6 dan 2.4 yang menghasilkan musiman dan sesuai dengan periode yang dihasilkan oleh periodogram. Pasangan vektor eigen tersebut berkolerasi tinggi antar keduanya dan tidak berkolerasi dengan yang lain. Panjang langkah grouping dilakukan sampai dengan 5 eigentriple dan terbentuk 3 kelompok yaitu tren (eigentriple 1), musiman 1 (eigentriple 2-3), dan musiman 2 (eigentriple 4-5). Sisanya yaitu eigentriple 6 sampai dengan eigentriple 26 dianggap sebagai noise.

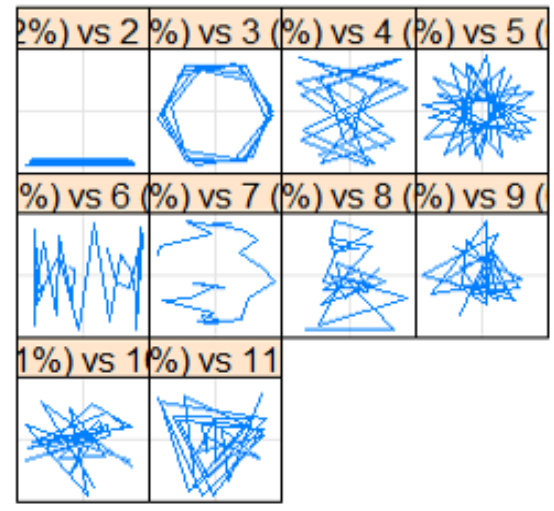

Gambar 2 Scatterplot untuk Pasangan Vektor Eigen dari Data

Pengecekan separability dari kelompok-kelompok yang telah terbentuk dilakukan dengan menggunakan matriks $w$-correlation. Matriks $w$-correlation menunjukkan korelasi antar komponen yang terbentuk. Semakin gelap warna yang terbentuk menunjukkan korelasi antar komponen semakin kuat. Pada Gambar 3, terlihat bahwa komponen pertama (F1) berkorelasi dengan dirinya sendiri dan tidak berkorelasi dengan komponen lainnya, komponen kedua (F2) berkorelasi kuat dengan komponen ketiga (F3), begitu juga sebaliknya, tetapi tidak berkorelasi kuat dengan komponen lainnya. Begitu juga untuk komponen keempat (F4) dan komponen kelima (F5). Jadi, dapat disimpuklan bahwa data listrik di DIY dapat didekomposisi menjadi 3 kelompok seperti dalam Tabel 1. 

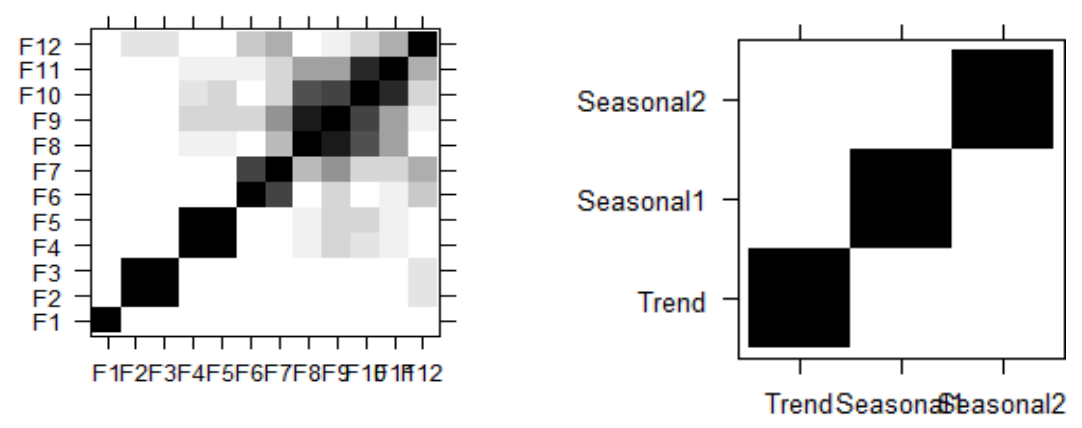

Gambar 3 Matriks W-correlation

Tabel 1 Pengelompokan Komponen Data Listrik DIY

\begin{tabular}{cll}
\hline Kelompok & Komponen & Eigentriple \\
\hline 1 & Tren & 1 \\
2 & Seasonal 1 & $2-3$ \\
3 & Seasonal 2 & $4-5$ \\
\hline
\end{tabular}
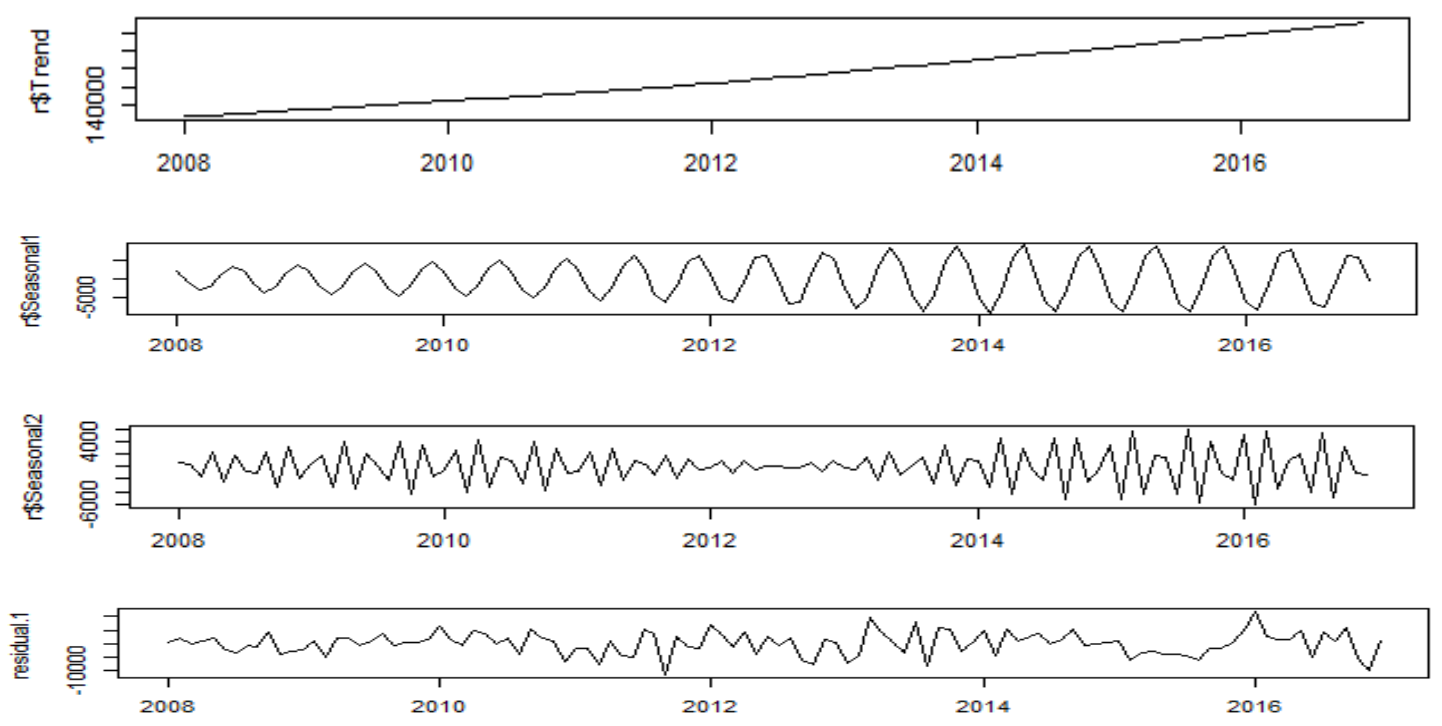

Gambar 4 Data Listrik DIY yang sudah Direkonstruksi dan Residu

Dari Gambar 4, tren yang terbentuk memiliki bentuk tak beraturan dan dibangun oleh suatu siklus dengan panjang yang berbeda. Komponen seasonal 1 menggambarkan siklus tahunan dan komponen seasonal 2 menggambarkan siklus setengah tahunan sesuai dengan periode yang dihasilkan dari periodogram. Diperoleh kesimpulan pula bahwa data mengikuti pola musiman dengan periode 6 . Hal ini berarti penggunaan listrik untuk periode Januari 2008 sampai dengan 2016 mengikuti pola musiman dengan periode 6 bulan.

Langkah terkhir adalah diagonal averaging dimana deret baru yang berupa series unidimensi akan dibentuk berdasarkan lima kelompok yang telah direkonstruksi pada tahap grouping. Tabel 2 menunjukkan hasil dari langkah diagonal averaging, data asli dan residual yang terbentuk. 
Tabel 2 Diagonal Averaging Data

\begin{tabular}{ccccccr}
\hline Waktu & $\begin{array}{c}\text { Komsumen } \\
\text { Listrik DIY }\end{array}$ & Tren & Musiman1 & Musiman2 & $\begin{array}{c}\text { Diagonal } \\
\text { Averaging }\end{array}$ & Residual \\
\hline Jan 2008 & 130.914 .2 & $128.128,7$ & $2.053,83$ & 615,12 & $130.797,6$ & 116,6 \\
Feb 2008 & 130.345 .8 & $128.600,3$ & $-627,83$ & 379,96 & $128.352,4$ & $1.993,4$ \\
$\ldots$ & $\ldots$ & $\ldots$ & $\ldots$ & $\ldots$ & $\ldots$ & $\ldots$ \\
Nov 2016 & $224.312,0$ & $229.449,1$ & $5.924,89$ & $-1.156,37$ & $234.217,6$ & $-9.905,6$ \\
Dec 2016 & $229.479,0$ & $230.455,1$ & $-566,82$ & $-1.433,31$ & $228.455,0$ & $1.024,0$ \\
\hline
\end{tabular}

Gambar 5 menggambarkan grafik dari data listrik (warna hitam) dan data hasil rekonstruksi (warna biru). Tampak bahwa pola data rekonstruksi SSA mengikuti pola data listrik DIY.

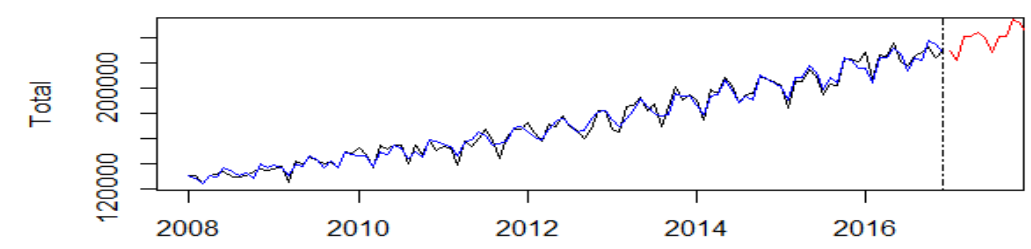

Gambar 5 Grafik Data Listrik DIY vs Rekonstruksi SSA

Selanjutnya akan dilakukan evaluasi model peramalan SSA-LRF yang diperoleh berdasarkan data in-sample dengan meramalkan 12 periode kedepan dan membandingkan hasil ramalan dengan data out sampel. Peramalan dengan menggunakan SSA membutuhkan koefisien LRF sebagai bobot pengali data sebelumnya. Diperoleh nilai hasil peramalan dengan menggunakan SSA pada Tabel 3. Nilai kesalahan ramalan dapat di lihat pada Tabel 4.

Tabel 3 Ramalan Data Listrik dan Data Out-Sample

\begin{tabular}{|c|c|c|c|c|c|c|c|}
\hline Tahun & Bulan & $\begin{array}{c}\text { Data } \\
\text { listrik } \\
\text { DIY }\end{array}$ & $\begin{array}{c}\text { Hasil } \\
\text { Peramalan }\end{array}$ & Tahun & Bulan & $\begin{array}{c}\text { Data } \\
\text { listrik } \\
\text { DIY }\end{array}$ & $\begin{array}{c}\text { Hasil } \\
\text { Peramalan }\end{array}$ \\
\hline \multirow[t]{12}{*}{2017} & Januari & 224693 & 225625.1 & \multirow[t]{12}{*}{2018} & Januari & 230164 & 237705.7 \\
\hline & Februari & 204834 & 214515.7 & & Februari & 211850 & 229092.1 \\
\hline & Maret & 230472 & 242090.1 & & Maret & 241465 & 255847.7 \\
\hline & April & 226027 & 245076.5 & & April & 242983 & 265627.2 \\
\hline & Mei & 235157 & 242039.9 & & Mei & 249244 & 255980.2 \\
\hline & Juni & 221078 & 208786.4 & & Juni & 222548 & 250397.8 \\
\hline & Juli & 221821 & 228813.6 & & Juli & 230703 & 249918.3 \\
\hline & Agustus & 228392 & 237649 & & Agustus & 229673 & 241635.5 \\
\hline & September & 225992 & 250851.3 & & September & 234298 & 245424 \\
\hline & Oktober & 242897 & 251852.1 & & Oktober & 259022 & 265810.6 \\
\hline & November & 231172 & 252649.8 & & November & 252448 & 268127.7 \\
\hline & Desember & 231946 & 242514.6 & & Desember & 252652 & 260002.4 \\
\hline
\end{tabular}

Tabel 4 RMSE, MAPE dan MAE Peramalan Data Listrik DIY dengan SSA-LRF

\begin{tabular}{ccrl} 
Data & RMSE & MAPE (\%) & MAE \\
\hline In-sample & $4.160,12$ & 1,91 & $3.373,25$ \\
\hline
\end{tabular}




\begin{tabular}{llll}
\hline Out-sample & $14.539,53$ & 5,61 & $12.961,90$ \\
\hline
\end{tabular}

Dari kesalahan ramalan menggunakan SSA-LRF pada Tabel 4, menunjukkan bahwa kesalahan out-sampel lebih besar dibandingkan kesalahan pada in-sampel. Untuk itu, sebaiknya model peramalan ini tidak digunakan untuk meramalkan jangka panjang. Tabel 5 berikut ini hasil ramalan untuk beban listrik DIY dari Januari 2019 sampai Desember 2024.

Tabel 5 Ramalan Beban Listrik Bulanan (MWH) di DIY

\begin{tabular}{llllllllllll}
\hline 2019 & & 2020 & \multicolumn{3}{c}{2021} & \multicolumn{2}{c}{2022} & \multicolumn{3}{c}{2023} & \\
\hline Jan & 250636.0 & Jan & 266922.5 & Jan & 288447.5 & Jan & 317485.9 & Jan & 353244 & Jan & 392641.7 \\
Feb & 275602.5 & Feb & 301921.9 & Feb & 324427.1 & Feb & 343287.6 & Feb & 359491.6 & Feb & 376815 \\
Mar & 271095.3 & Mar & 289647.1 & Mar & 313226.2 & Mar & 341292.1 & Mar & 371086.5 & Mar & 399351 \\
Apr & 285330.1 & Apr & 303075.9 & Apr & 318241.8 & Apr & 333115 & Apr & 350353.5 & Apr & 372352.1 \\
Mei & 272246.9 & Mei & 290743.6 & Mei & 311150.2 & Mei & 331267.7 & Mei & 350422.9 & Mei & 368887.3 \\
Jun & 262792.9 & Jun & 277628.4 & Jun & 296298.3 & Jun & 321792 & Jun & 354080.2 & Jun & 390888.4 \\
Jul & 273823.6 & Jul & 298100.7 & Jul & 320366.8 & Jul & 339523.6 & Jul & 357428.3 & Jul & 377578.3 \\
Agu & 268648.1 & Agu & 290108.7 & Agu & 318360.8 & Agu & 351939.7 & Agu & 388144.7 & Agu & 422469.4 \\
Sep & 298778.9 & Sep & 319451.8 & Sep & 336272.9 & Sep & 350759.7 & Sep & 366397.5 & Sep & 386741.4 \\
Okt & 282425.2 & Okt & 301768.2 & Okt & 325248.4 & Okt & 349148.5 & Okt & 371958.5 & Okt & 392548.8 \\
Nov & 282686.8 & Nov & 297053.3 & Nov & 313531.7 & Nov & 334434.4 & Nov & 361061.8 & Nov & 392556.7 \\
Des & 280168.2 & Des & 300692.9 & Des & 320740.7 & Des & 338983.8 & Des & 356933.9 & Des & 377904.5 \\
\hline
\end{tabular}

Performa ramalan di tunjukkan pada Gambar 6. Dari gambar tersebut terlihat adanya kecenderungan kenaikan beban listrik bulanan di DIY.

Dari penelitian-penelitian terdahulu, Fitriani dkk (2015) menggunakan metode hybrid autoregressive integrated moving average-neural network untuk meramalkan beban puncak pemakaian listrik Jawa Tengah dan Daerah Istimewa Yogyakarta, diperoleh model terbaik dengan mean square error (MSE) 188.330,694. Nugraheni (2015) juga telah memodelkan peramalan kebutuhan listrik bulanan di DIY menggunakan metode fuzzy radial basis function neural network berdasarkan data dari Januari 2007 sampai Desember 2015 dengan MAPE 7,94\% untuk data in-sample dan 9,73\% untuk out-sample. Peramalan beban listrik tahunan di DIY menggunakan neural network backpropagation menghasilkan mean absolut deviation 961.750 KWH (Pratama, 2016).

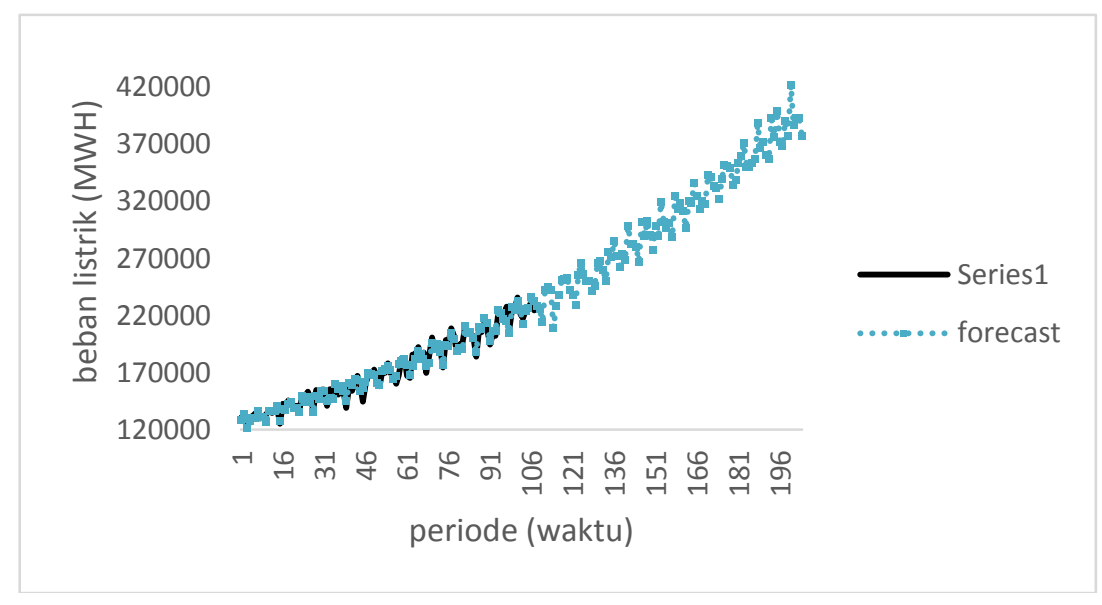

Gambar 6 Plot Ramalan vs Data Asli 


\section{KESIMPULAN}

Dari penelitian ini diperoleh kesimpulan bahwa metode SSA-LRF merupakan salah satu metode alternatif yang bisa digunakan untuk memprediksi besarnya konsumsi beban listrik di Yogyakarta dengan MAPE 1,91\% pada in-sampel dan 5,61\% pada out-sampel. Sedangkan hasil ramalan untuk tahun 2019 sampai 2024 di tunjukkan pada Tabel 5 dan di gambarkan pada Gambar 6.

\section{DAFTAR PUSTAKA}

Afsar, R. dan Bigdeli. 2011. Data Analysis and Short Term Load Forecasting in Iran Electricity Market Using Singular Spectral Analysis (SSA). Energy, Vol.36, hal. 2620-2627.

Dafroni, L.P., Suyono, H., dan Hasanah, R. N. 2015. Peramalan Beban Listrik Daerah Istimewa Yogyakarta Tahun 2015-2025 dengan Metode Ekonometrik. Jurnal Mahasiswa TEUB, Vol. 3, No. 5.

Elsner, J.B. dan Tsonis, A.A. 1996. Singular Spectrum Analysis, A New Tool in Time Series Analysis. Springer Publisher.

Fitriani, B. E., Ispriyanti, D., dan Prahutama, A. 2015. Peramalan Beban Pemakaian Listrik Jawa Tengah dan Daerah Istimewa Yogyakarta dengan Menggunakan Hybrid ARIMA-NN. Journal Gaussian, Vol. 4, No.4, hal. 745-754.

Ghil, M. dan Vautard, R. 1991. Interdecadal Oscilations and the Warming Trend in Global Temperature Time Series. Nature, Vol. 350, pp. 324-327.

Golyandina, N.E. dan Korobeynikov, A. 2014. Basic Singular Spectrum Analysis and Forecasting with R. Computational Statistics \& Data Analysis.

Golyandina, N. Nekrutkin, V. Zhigljavsky, A. 2001. Analysis of Time Series Structure:SSA and Related Techniques. Chapman and Hall/CRC. United States of America.

Golyandina, N.E. dan Zhigljavsky, A. 2013. Singular Spectrum Analysis for Time Series. SpringerBriefs in Statistics.

Harmawan, S. 2013. Peramalan Beban Listrik Harian Jawa Tengah dan Daerah Istimewa Yogyakarta Menggunakan Metode Seasonal Autoregressive Integrated Moving Average. Skripsi UGM. Yogyakarta.

Hassani, H. 2007. Singular Spectrum Analysis: Methodology and Comparison. Journal of Data Science. Vol. 5, hal. 239-257.

Hassani, H. 2009. Development of The Theoretical and Methodological Aspect of The Singular Spectrum Analysis and Its Application for Analysis and Forecasting of Economics Data. Disertasi. Cardiff University. Inggris Raya.

Lubis, D.A. Johra, M.B. dan Darmawan, G. 2017. Peramalan Indeks Harga Konsumen dengan Metode Singular Spectrum Analysis (SSA) dan Seasonal Autoregressive Integrated Moving Average (SARIMA). Jurnal Matematika "MANTIK", Vol. 3, No. 2, hal. 74-82. 
Nugraheni, R.A. 2017. Model Fuzzy Radial Basis Function Neural network Untuk Peramalan Kebutuhan Listrik di Propinsi Daerah Istimewa Yogyakarta. Skripsi. Universitas Negeri Yogyakarta.

Pamungkas, W.P. 2013. Peramalan Beban Listrik Harian Jawa Tengah dan Daerah Istimewa Yogyakarta Menggunakan Metode Double Seasonal Eksponensial Smoothing. Skripsi UGM. Yogyakarta.

Pratama, R.A. dan Anifah, L. 2016. Peramalan Beban Listrik Jangka Panjang Propinsi D.I Yogyakarta Menggunakan Neural Network Backpropagation. Jurnal Teknik Elektro, Vol. 5, No. 3, hal. 0-47.

Ringwood, J. V. dan Bofelli, D. 2001. Forecasting Electricity Demand on Short, Medium, and Long Time Scales Using Neural Networks. Journal of Intelligent and Robotic Systems. Vol. 31, hal. 129-147.

Rosmalawati, M. A., Handoko, B., Sunengsih, N., dan Darmawan, G. 2014. Automatisasi Grouping pada Singular Spectrum Analysis (SSA). Proceeding Seminar Nasional Statistika UNPAD.

Setiawan, H. 2014. Konversi BBM ke BBG : Belajar dari Pengalaman. Info Risiko Fiskal Edisi 1.

Vautard, R. dan Ghil, M. 1989. Singular Spectrum Analysis in Nonlinear Dynamics with Applications to Paleoclimatic Time Series. Physica D : Nonlinear Phenomena. Vol. 35, hal. 395-424.

Vautard, R., Yiou, P., dan Ghil, M. 1992. Singular Spectrum Analysis : A Toolkit for Short, Noisy Chaotic Signals. Physica D:Nonlinear Phenomena. Vol. 1-4, hal. 95126.

Weron, R. dan Misiorek, A. 2008. Forecasting Spot Electricity Prices : A Comparison of Parametrik Time Series Models. International Journal of Forecasting. Vol. 24, hal. 744-763. 